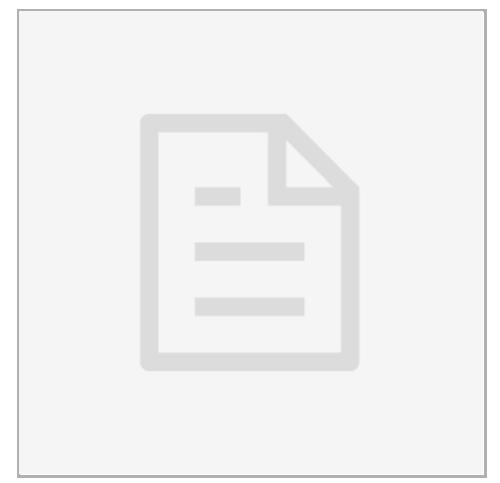

JUL 31, 2020

\section{(3) SOLUTION- 11 - CD4+T cells isolation buffer}

Marco Cosentino ${ }^{1}, \quad$ Elisa Storelli ${ }^{1}$, Alessandra Luini ${ }^{1}$, Massimiliano LM Legnaro ${ }^{1}$, Emanuela Rasini ${ }^{1}$, Marco Ferrari ${ }^{1}$, Franca Marino ${ }^{1}$

${ }^{1}$ Center for Research in Medical Pharmacology, University of Insubria (Varese, Italy)

\section{Farmacologia Medica}

\section{open ठaccess}

\section{DOI:}

dx.doi.org/10.17504/protocol s.io. bi79khr6

\section{Document Citation: Marco}

Cosentino, Elisa Storelli, Alessandra Luini, Massimiliano LM Legnaro, Emanuela Rasini, Marco Ferrari, Franca Marino 2020. SOLUTION- 11 - CD4+T cells isolation buffer. protocols.io

https://dx.doi.org/10.17504/p rotocols.io. bi79khr6

License: This is an open access document distributed under the terms of the Creative Commons Attribution License, which permits unrestricted use, distribution, and reproduction in any medium, provided the original author and source are credited

Created: Jul 31, 2020

Last Modified: Jul 31, 2020

DOCUMENT integer ID: 39905

Composition $\mathrm{g} / \mathrm{ml}$ : 
EDTA $0.2235 \mathrm{~g}$

Add PBS(Ca2+ and Mg2+ free) to $240 \mathrm{ml}$, adjust to $\mathrm{pH} 7.4$ with $\mathrm{NaOH}$ or $\mathrm{HCl}$, bring to $250 \mathrm{ml}$ with PBS.

The substances are in the closet 1 and in refrigerator 1 (Room TSO8), weigh the substances with Gibertini balance (Room TSO8).

Filter this buffer by using a sterile syringe and filter.

Sterile filters and syringes are in closet 1 (Room PSO3).

Storage: $8^{\circ} 4^{\circ} \mathrm{C}$ refrigerator 2 - (Room PSO3).

BSA: catalog number A2153, Sigma, Italy

EDTA: catalog number ED2SS, Sigma, Italy

Prymo siringe filter: catalog number EPSPE2230 Euroclone, Italy. 